\title{
LOCAL AND SUSTAINABLE POTENTIAL APPROACHES IN THE DESIGN OF A MASTER PLAN ARCHITECTURE: CASE STUDY OF PAKSEBALI TOURISM VILLAGE DEVELOPMENT, INDONESIA
}

\author{
I Kadek Merta WIJAYA* \\ Warmadewa University, Department of Architecture, Bali, Indonesia, e-mail : amritavijaya@gmail.com
}

\begin{abstract}
Citation: Wijaya, I.K.M. (2021). LOCAL AND SUSTAINABLE POTENTIAL APPROACHES IN THE DESIGN OF A MASTER PLAN ARCHITECTURE: CASE STUDY OF PAKSEBALI TOURISM VILLAGE DEVELOPMENT, INDONESIA. GeoJournal of Tourism and Geosites, 36(2spl), 571-579. https://doi.org/10.30892/gtg.362spl03-685
\end{abstract}

\begin{abstract}
This research aimed to plan the design of the master plan through a local potential and sustainable approach in creating a master plan architecture Paksebali tourism village. The research methods used are Research and Development (R\&D) method in qualitative research. The first step was carried out with a study of the Paksebali Tourism Village to find the right approach's characteristics and then develop it in the form of an architectural design of a tourist village master plan. This study's results indicate that the master plan for Paksebali Tourism Village is based on developing supporting facilities for local potentials by maintaining these potentials' sustainability, which is implemented in master plan designs both macro and micro. This sustainability is fundamental as the consistency of this potential is conservative, maintains local characteristics, and beco mes a welfare source for local communities. The Paksebali Tourism Village master plan's architectural design transformation requires these considerations (local potential and sustainability).
\end{abstract}

Key words: community-based, local potential, master plan architecture, Paksebali tourism village, sustainability

\section{Introduction}

Tourism villages are a new perspective in the tourism sector (Komariah et al., 2018; Sesotyaningtyas and Manaf, 2015; Trisnawati et al., 2018). This model emerged as a response to the tourism development model, which prioritizes individual and group interests. Exploring tourism potential without paying attention to the sustainability and contextual aspects of local communities is a phenomenon that is developing worldwide. This generally occurs in mass tourism, where tourists come to tourist objects in droves in large numbers (Butler, 1999; Juan et al., 2016; Marson, 2011; Vainikka, 2013). This mass tourism positively impacts economic development and affects environmental and social degradation (Buckley, 2007; Fennell, 2008; Vainikka, 2013). Focus on financial aspects and not paying attention to the sustainability aspects of the explored environment and distant social relations between communities due to economic competition. In various countries globally, there is a change in tourism development towards quality tourism by offering exclusive travel and maintaining environmental and social sustainability (Fennell, 2008; Pan et al., 2018). There was an exploration of the natural environment without regard to supporting ecological resources for the future. There was also the construction of tourist accommodation facilities without considering the impact on the ground. Tourism area planning must pay attention to local aspects and pay attention to their ecological impacts (Gohar and Kondolf, 2016). The transition of vernacular and traditional settlement architecture to commercial architecture, for example, is a form of commercialization of the interests of the selling value of tourism, where vernacular and traditional architecture could become tourist destination artifacts, not converted into commercial architecture. Some changes have occurred in the spatial layout of community residential units, which have changed their function to become an art shop. However, visually, the facades of the buildings still retain local architectural characteristics. The presence of tourism accommodation architecture such as lodging and restaurants with an architectural style that was not contextual on the site being built, changed the identity of a place with a new identity. The above phenomenon is the basis for the emergence of a Tourism Village in the tourism industry, with the concept of existence, independence, and sustainability of village assets through independent management by the village themselves. Tourism village assets which are local potentials as objects of tourist destinations can be in the form of rural nature, natural attractions, traditions, and other unique elements that attract tourists (Joshi, 2012). The local community is expected to be able to maintain the sustainability of natural, cultural, and other potentials, as tourism actors in the management of tourism village governance (Wijaya, 2020; Yanes et al., 2019).

The tourist village has components that synergize with one another in realizing the main goal: local communities' welfare. According to Prasyanti et al. (2018), tourism village components consist of soul, body, and mind. Soul has a connection with local potentials as a tourist asset, such as natural, cultural, and traditional potential, and other villages that can be used as tourist assets. The body is a tourist village's infrastructure to support the village's potential, namely roads, tourism accommodation facilities, and other hospitality facilities. The mind correlates with hospitality and management. The potential as the main asset of a tourist village and village infrastructure will not work together if there is no tourism management (mind). Local communities are carried out, which are expected to be independent in managing their tourism assets. The community approach is an effort to maintain village assets as the main aspect of the Tourism Village through the local community's 
independence in managing their village (Adebayo et al., 2019; Okazaki, 2008; Wijaya, 2020; Wijaya and Nurwarsih, 2019). This strategy is a core component of ecotourism or tourism focused on the climate. Ecotourism is described as a tourist trip to a remote location to enjoy and learn about the potential of nature, culture, and customs while also benefiting the local economy. (Cater and Cater, 2015; Cobbinah, 2015; Fennell, 2008). Ecotourism is a form of tourism that focuses on natural and cultural resources through knowledge, awareness, and restoration (Masjhoer et al., 2017). On January 19, 2017, Klungkung Regent Regulation No.2 of 2017 named Paksebali Village as a tourism village. This determination is based on the potential of Paksebali Village as a tourism village. Paksebali Village has natural areas in Tukad Unda and Bukit Mandean, which can provide a panoramic view of natural beauty in river water flow that terraces up to the green hilltop visual beauty hilly area (Wijaya, 2020). The preservation of both sacred and secular art traditions in the village of Paksebali is still well preserved to this day. As a product of religious culture, Temple architecture provides an overview of local architecture development in Paksebali Village. Community independence in the economic sector through community activity units in the form of local crafts and local culinary is an essential part of the assets of the village of Paksebali as a Tourism Village (Pantiyasa and Rosalina, 2018).

The tourism potentials possessed by the Paksebali Tourism Village are scattered in the Paksebali Village area with a considerable distance from one prospect to another (Wijaya, 2020). This distribution is a concept in a tourist village that provides a tourist movement scenario through the "tour around village" approach. However, this was not supported by an information center's existence and the capacity of tourism support facilities to provide comfort and security for the Paksebali Tourism Village visitors. The concept of the soul - village assets as tourism potential, body - infrastructure and capacity of supporting facilities, and mind - tourism village management that prospects in Paksebali Village. The destination object was not supported by the presence of a "body of tourism village," thus, the comfort and safety of visitors were reduced in its hospitality value. Tourists could not know the tourist destination spots, the unavailability of tourist attractions to improve the local economic aspects, and tourists have not enjoyed local dance tourism attractions optimally because it has not been accommodated in performance architecture. Rest areas were still minimal in supporting tourist visits to the village. According to the above definition, the tourist village elements in the form of "soul," "bone," and "mind" are at odds with the reality in the area. This means that the Paksebali Tourism Village did not have the concept of developing a tourism area that is integrated between "soul," "body," and "mind" in a tourist area to support the local welfare of the Paksebali Village residents in the independent management of the tourism village. The potential of Paksebali Village can be seen in Figure 1. The study aimed to develop Paksebali Tourism Village in a master plan planning with a sustainability approach. The scenario offered is that the potential possessed by Paksebali Village is the main asset in developing a tourism village while still prioritizing the distinctive aspects of each potential, not carrying a design concept from outside Paksebali Village but adopting the local wisdom of Paksebali Village. Can be done through a sustainable master plan, namely (1) planning for the arrangement of the Tukad Unda and Bukit Mandean areas oriented to a contextual design; (2) accommodating the activities of cultural traditions such as local dances in a space (stage); (3) supporting the development of community activity units in the field of local crafts as tourist objects; and (4) planning an

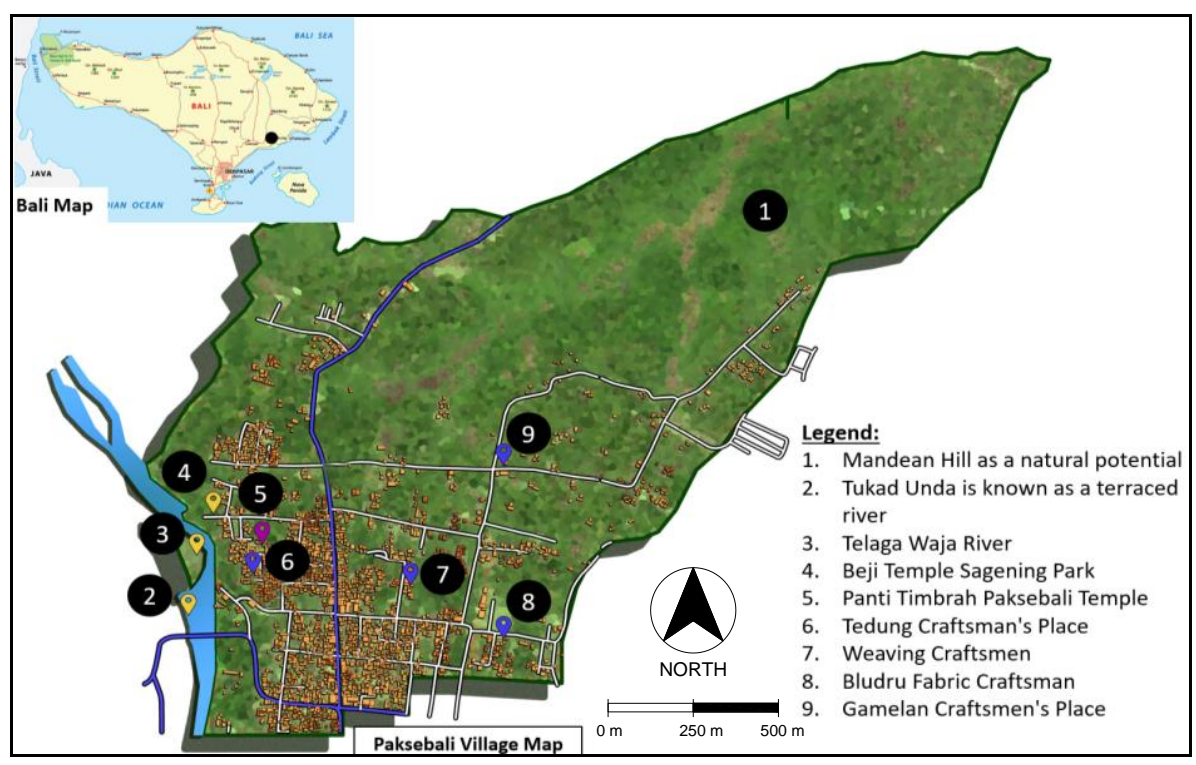

Figure 1. Spreading the Potentials of Paksebali Tourism Village (Source: Author, 2021) information center as a starting point

for excursions in Paksebali Village, serving information about Paksebali Village, restaurant facilities that present local menus with a modern appearance, galleries to display the local handicrafts of Paksebali village and information about village traditions, also the management room for the tourism area of Paksebali Village. This scenario is following the concepts of "soul," "body," and "mind," as well as the idea of sustainability in protecting nature (environment), economic sustainability, and social relations between visitors and local communities in a setting that is still natural.

\section{MATERIALS AND METHODS}

The research method used in this research was research and development (R\&D). This method emphasizes two main stages: a study in the form of research and development in design. This method aims to produce a particular product and test its effectiveness (Hamzah, 2019; Sugiono, 2016). The research stage focuses on grand concepts to see and limit analysis and searching or data collection (Muhadjir, 2002). The development stage is in the form of design, development, testing, and reporting. This stage focuses on implementing the research results, namely the sustainability concept, in the master plan design for Paksebali Tourism Village. The grand concept serves as a starting point for developing the master plan for the Paksebali Tourism Village district. The elegant concept used is the sustainability concept - economic, environmental, and social. The 
master plan design towards has the approaches aimed at directing the existence of the local potentials of Paksebali Tourism Village. The involvement of local communities in the operational and conservative management of these tourism assets, maintaining the independent presence of local communities, and reducing the effects of development and architectural forms outside the context of the Paksebali Tourism Village can change the characteristics of Paksebali tourist village. The analysis out through data collected through structured interviews and observations. The data collection method was carried out to identify Paksebali Tourism Village's potentials in nature, culture, local crafts, and local culinary. The identification was carried out based on biological, cultural, and traditional variables, local arts, and local culinary delights. The units of information identified are relevant to the purpose of this research. The results of this data collection were translated into architectural planning, which was divided into four zones, namely (1) the Bukit Mandean zone; (2) the information center zone in the Tukad Unda (Unda river) area; (3) the zone where the performance is located; and (4) the glamping zone.

The development of a tourism village through consideration of sustainability - economic, environmental, and social aspects can be detailed as follows:

1. They are planning in the economic aspect through the method of interaction of local communities in tourism activities to get welfare from these tourism activities. The vernacular architectures as tourist accommodation through the tourist house approach, a large amount of capital, is not required in tourist accommodation.

2. Planning in the social aspect, namely, equitable distribution of community interactions in tourism activities so that the benefits are evenly distributed. There is no form of social jealousy among the village community, and social relations are well established through intense communication in cooperation in managing the sustainability of these local potentials.

3. Planning in the environmental aspect, namely through the interaction of the local community in running a tourist village, a strong sense of belonging is a tremendous asset in maintaining the sustainability of these local potentials. The involvement of village awig-awig (customary regulations) is the proper method in maintaining these potentials because local people are very obedient to the ordinary local rules.

This research's steps are divided into two main stages: research and development (Hamzah, 2019; Sugiono, 2016). The research stage was carried out through a qualitative study to find concepts and approaches in designing the master plan for the Paksebali Tourism Village. The development stage consists of (1) reviewing the images and elements of a tourist village; (2) identifying the existing conditions of Paksebali Tourism Village and the development of tourism in the context of a tourist village; (3) finding the gaps and weaknesses of Paksebali Tourism Village based on the concept of "soul," "body" and "mind"; (4) formulating a development program based on elements of a tourist village ("soul," "body" and "mind"); (5) composing a tourism village development model with the local character through a sustainability approach; (6) planning a master plan for the development of the tourism village of Paksebali which is divided into two programs, namely macro and micro; and (7) synthesizing the planning model analysis. These research steps are implied in the research flowchart below (Figure 2):

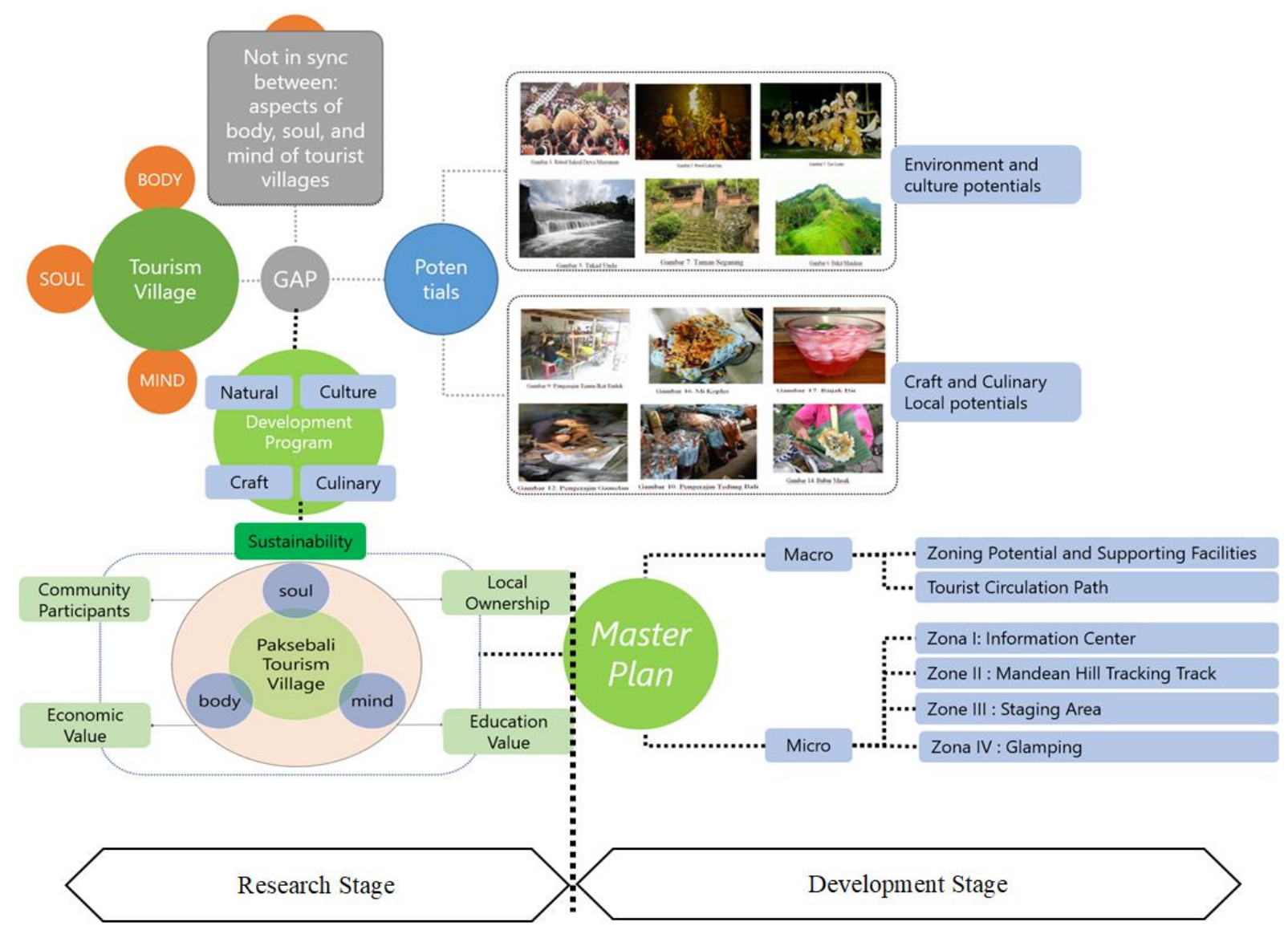

Figure 2. Stages of Research and Development (R\&D) (Source: Author, 2021) 
The picture above shows a gap between a tourism village's concept and the existing conditions of the Paksebali Tourism Village. The central idea of a tourist village is the empowerment of local communities towards village independence. Community empowerment creates a concept of the sustainability of local potentials that are owned because a tourist village aims to create a sustainable local potential for the future. The local potential is the main asset of a tourist village; its existence needs attention in governance and conservatism. Proper authority and conservatism involve the local community so that the welfare created is from the people and for the people.

\section{RESULTS AND DISCUSSION}

\section{Potential and Problems in Paksebali Tourism Village}

Paksebali Tourism Village is one of the tourist villages in the Klungkung Regency (Wijaya, 2020). As a tourism village, Paksebali Village has the potential to attract tourists. The attraction of these potentials is a soul of a tourism village in Paksebali Village that must be maintained for its sustainability. These potentials consist of (1) natural potential, (2) cultural potential, (3) local craft potential, and (4) local culinary potential. This potential makes Paksebali Village a tourism village based on Surat Keputusan Pemerintah Kabupaten Klungkung, established in 2017. These potentials will not run according to the Tourism Village's objectives if they are not supported by management and infrastructure. Management aspects in accommodating hospitality facilities because the concept of a tourist village depends more on local communities' elements in governance for local communities' welfare and preserving the natural environment. Usually, exploration of tourism potentials or assets is aimed at the benefit (money) aspect rather than maintaining the sustainability or preservation of this potential for the common welfare. It has become a growing phenomenon in the tourism industry (Juan et al., 2016; Marson, 2011; Vainikka, 2013).

Paksebali Village has natural potential in the Mandean Hill area upstream of the village and the Tukad Unda area in Paksebali Village. Between these areas, there is a residential zone. Mandean Hill is an area that is still natural and calm, overgrown with various types of vegetation. You can see a view of the mountains and settlements in a 360-degree rotation on this hill. On the downstream side, there is Tukad Unda, which is the largest river in Klungkung and is the path of the floodwaters from the eruption of Mount Agung. This area's specialty is that it has terraced land that forms a river flow like a water curtain (Pantiyasa and Rosalina, 2018; Wijaya, 2020). This natural potential is an attraction for adventurous tours and tours that prioritize visuals or views. Other prospects still exist today as part of religious traditions and rituals. In Paksebali Village are the sacred rites of the Lukat Gni tradition, Dewa Masraman, the Lente Dance tradition, the Subali Mascot Dance, and the Ngelawang DanceThese dances can only be enjoyed or watched during religious ritual activities at each temple in Paksebali Village. The material form of culture is in the temple architecture, which has a historical background with a natural context and a traditional village context. In celebrating the community's independence, Paksebali Village has micro, small, and medium enterprises (UMKM) active in local handicrafts such as velvet literature, Ikad Endek weaving, Balinese building, glass painting, and Balinese gamelan. The marketing of these products is local, domestic, and even overseas. Another potential that this village has is local culinary delights, which can only be found in traditional markets. However, this potential is undoubtedly a unique attraction in supporting the existence of the Paksebali Tourism Village.

The existence of a tourism village is supported by its potential and infrastructure aspects and management. It promotes ecological tourism through coherent facility planning in infrastructure provision, service development, and planning thematic tourist routes to reach all potential tourism villages (Bica and Florescu, 2017). As a Tourism Village, it is a challenge for Paksebali Village to move the concept of a tourist village with a local character in its people's welfare. Related to the above, the phenomenon that has developed in Paksebali Village based on the results of the grand tour and interviews with tourism awareness groups is (1) the circulation to and from tourism potentials was still unclear and unregulated, considering that the distribution of tourism potential was far apart while clear directions for circulation were not yet available; (2) the map of the distribution of village potentials did not clearly define or describe the advantages of each potential as a tourist attraction; (3) the Mandean Hill area did not yet have a tourist character according to its potential, the current development was only as a place for selfies by visitors; (4) there were temple architectures that have a history of the existence of villages and natural environments, which have not been clearly identified; (5) tourists could not enjoy traditional dance performances because the performances take place at night and are incidental; (6) information about local handicrafts has not been clearly exposed to visitors; and (7) tourism support facilities were not available in every tourist spot. The above problems require planning solutions that are synergistic between tourism support facilities, the sustainability of local potentials, and local communities' welfare. The grand concepts used in the embodiment and layout of the master plan are sustainability - economic, social, and environment (Asmin, 2014; Mihalic, 2016; Wijaya and Nurwarsih, 2019).

\section{Architectural Design in The Macro Context}

At the macro scale, the architectural design plans a master plan by grouping tourism support facilities in Paksebali Village. This grouping is based on a sustainability approach. Economic sustainability is carried out by providing a display room for local handicrafts in the information center building. Tourists who come are directed to the information center as a starting point for their tours; visitors can see and enjoy local handicraft products equipped with each product's history. If tourists want to see local handicraft production activities, tourists will be escorted by the local guide of Paksebali to the intended place. The presence of a craft display building in the information center complex is an effort to guide visitors in exploring handicrafts interested in buying them. The same applies to local culinary delights, namely, providing restaurants with modern packaged local food menus. Meanwhile, social sustainability can be applied by providing shared facilities that form good communication between visitors and local communities, namely local craft spots and a tourist house intended for tourists who want to stay overnight in Paksebali Village. Visiting tourists can spend their time walking and interacting with residents. On the other hand, 
environmental sustainability is carried out by formulating a planning concept with tourist activities concentrated in the information center in the Tukad Unda area and not sporadically enjoying the natural beauty of Mandean Hill. Tourists who come to Mandean Hill must be escorted by a local guide to avoid illegal tourists (Figure 3).

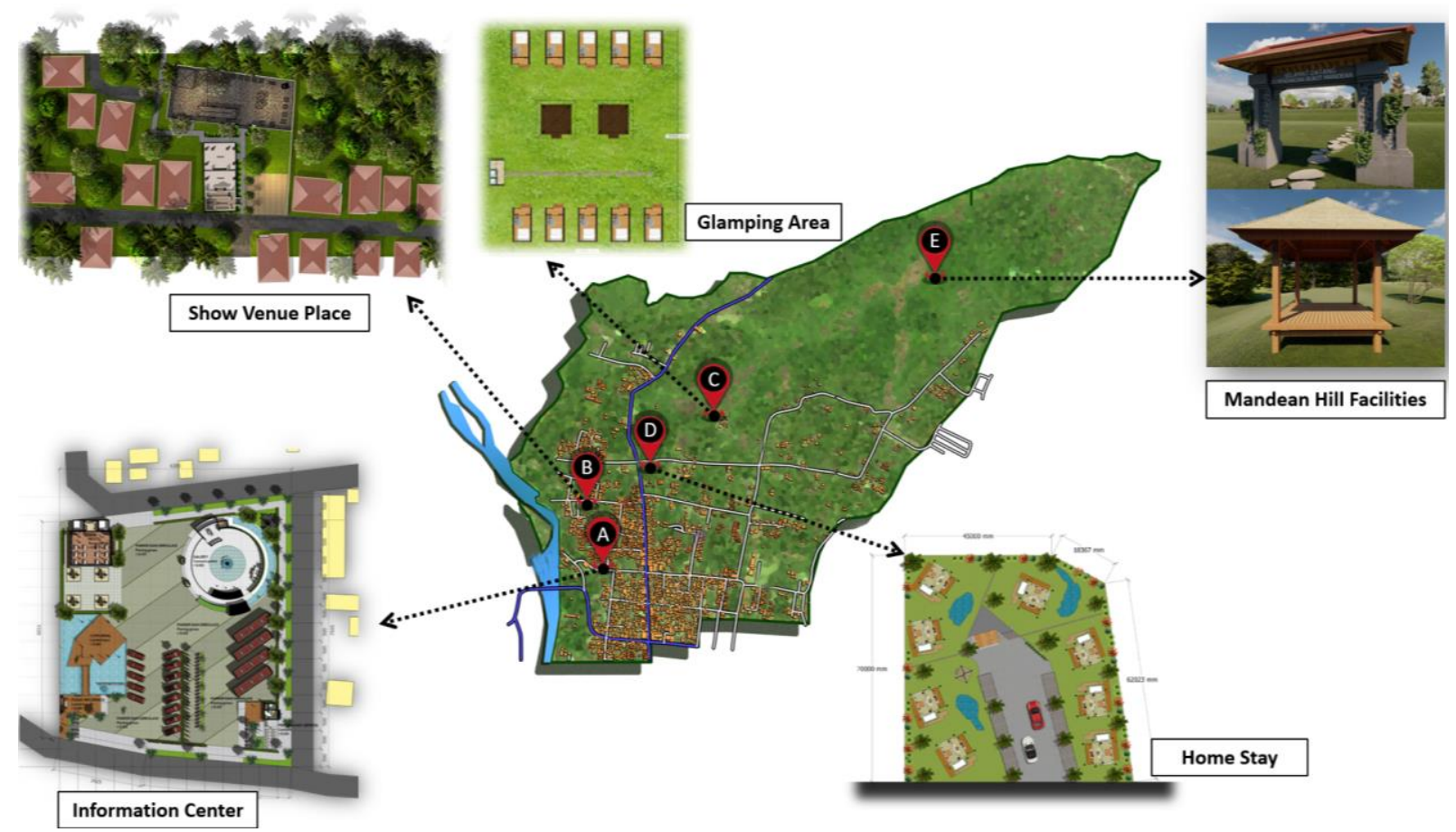

Figure 3. Paksebali Tourism Village Development Master Plan Planning (Source: Author, 2021)

\section{Architectural Design in The Micro Context}

a. Information Center Design

Information center planning aims to focus and direct visitors who come to a tourist facility-respond to a problem regarding the unclear circulation of visitors that has been happening in Paksebali Tourism Village. The circulation concept is to spread, which first meets or centers in one place (information center). The radial or diffuse circulation has one common point, applies in all directions, has a large area, and has a close relationship between spaces (Ching, 2009). The Information Center is planned with the primary function as a forum to provide information about Paksebali Tourism Village for tourists who come to visit. Carrying Bamboo Architecture's theme, this information center building was made to preserve the village's original characteristics and be environmentally friendly (Khatib, 2009; Manandhar et al., 2019). Tourists start their journey by entering the information center facility to obtain precise information, either in the form of a map of tourism potential in Paksebali Village that is interesting to visit or other information. Also, visitors can take a short break or sit back and enjoy the Telaga Waja River's view in the Communal Room before starting their tour of Paksebali Village.

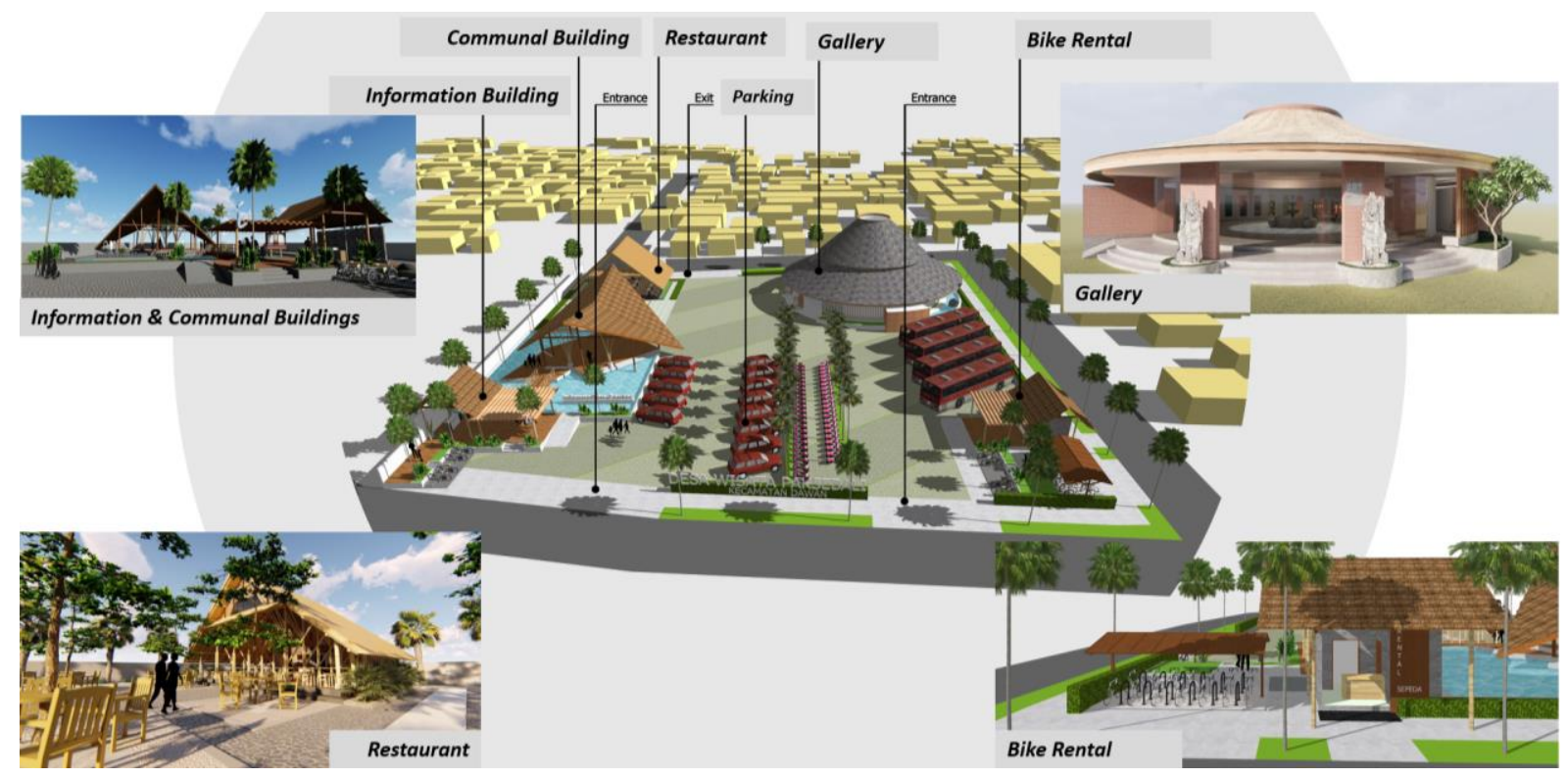

Figure 4. Information Center Planning (Source: Author, 2021) 
The information center consists of several building periods, namely (1) the information center building; (2) communal space, (3) restaurant, (4) gallery, (5) rental; and (6) parking lots for vehicles. This information center complex is located in the downstream part of the Paksebali Tourism Village, adjacent to the Tukad Unda (Unda River) area. All periods of the building are directed to Tukad Unda (Unda River) view so that the value of wellness as part of the hospitality concept for visitors is well achieved. The existence of restaurant buildings and local craft galleries is a manifestation of the "body of tourism villa" and the sustainability of the local community's economic aspects. The products displayed are the local handicrafts and culinary delights of the Paksebali Tourism Village community, so this tourism activity is for the local community's welfare. Environment sustainability is translated into the concept of using natural energy for ventilation and lighting through semi-open buildings to include sunlight and ventilation cross-circulation. According to the idea of tropical architecture, the building adapts to a low environment and is environmentally friendly (Hardiman, 2012; Manurung, 2014; Nugroho, 2018) (Figure 4).

b. Design of Cultural Performance Venues

This cultural venue is a tourist facility to accommodate the traditional performances of the Dewa Mesraman and Lente Dance. This facility is located on the side or offensive zone of the complex of Pura Panti Timbrah. So far, this traditional performance has taken place in Pura Panti Timbrah. However, this activity's proper facilities still do not provide a hospitality atmosphere if it is a tourist attraction for cultural performances. Therefore, a performance facility is planned in a Wantilan building and a parking lot as a service function. This plan aims to revive and exist Dewa Mesraman and Lente Dance's traditions as a form of cultural sustainability and establish social relationships between visitors and the community (tourism actors) through this activity. Culture sustainability is concerned with maintaining cultural beliefs, cultural practices, conservation of heritage, culture as its entity, and efforts to answer whether a given culture will exist or not in a future context (Packalén, 2010; Soini and Birkeland, 2014; Throsby, 1995) (Figure 5).

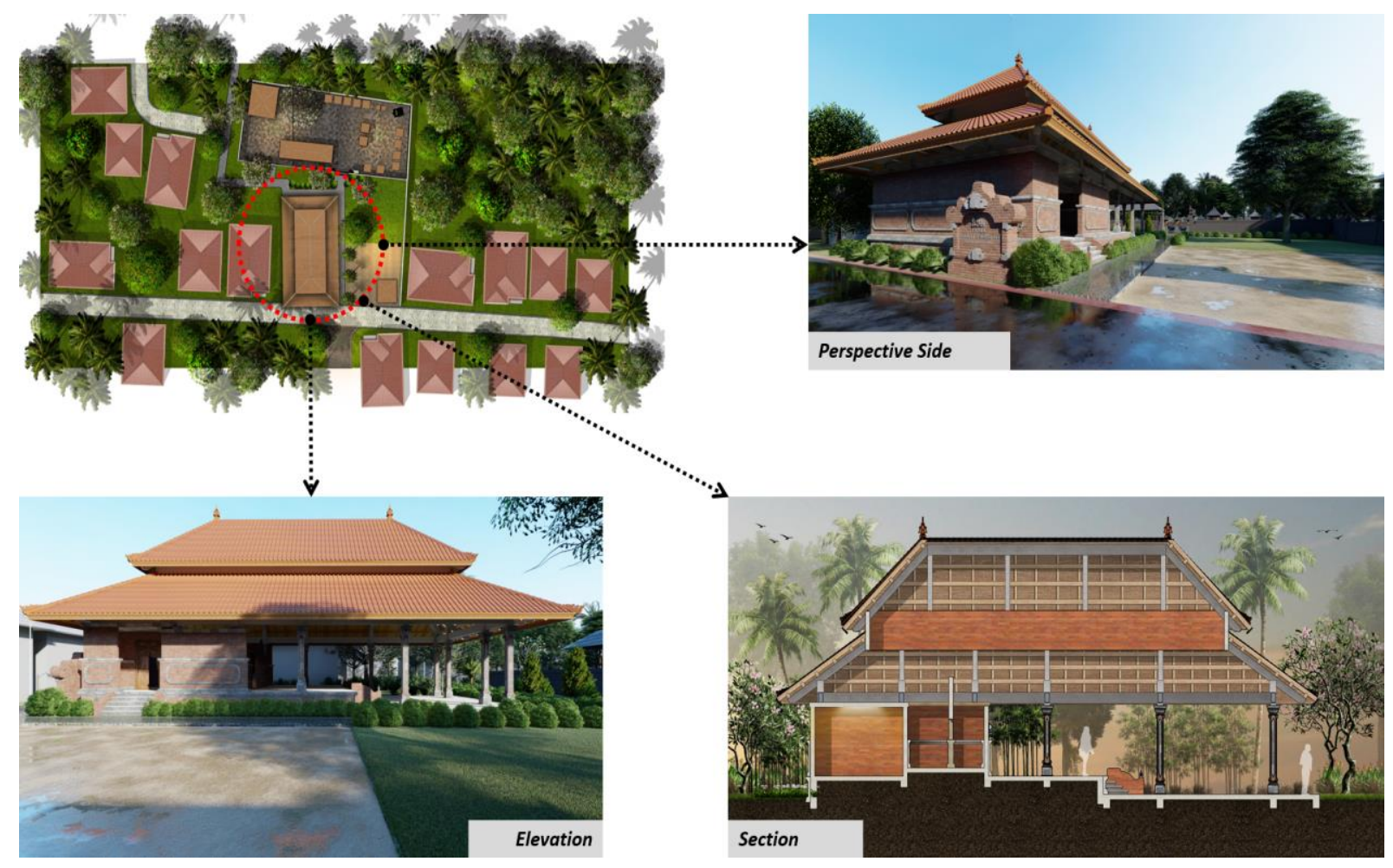

Figure 5. Show Venue Design (Source: Author, 2021)

c. Glamping Area Design

Planning a Glamping Area is an additional facility in Paksebali Tourism Village. The village's natural environment's carrying capacity is still raw and an attraction for tourists to stay at Paksebali Tourism Village. Glamping describes a camping style with resort-style amenities and services not typically associated with "traditional" camping (Budiasa et al., 2019; Craig, 2020; Josipa et al., 2017). The architectural formation used by this glamping architecture is to take the primary form of the Jineng or rice barn. Tourists only come and rent a semi-permanent campsite, and there are service facilities in the form of toilets and showers. Usually, at camp, visitors bring a tent to stay in and enjoy the village's natural atmospher e. However, the concept of glamping is to reduce the damaging impact on the environment through supervisory management by the local community. This camp or glamping provides ten glamping points with a total area of $142.8 \mathrm{~m}^{2}$ with a capacity of 2-4 people in one room. The glamping design is made using a semi-permanent wooden structure. The building's shape, which adopts the granary/Jineng form, is dominated by wood as the finishing material (Figure 6). In this camping area, there are also public toilets and a standard room in a gazebo form. With a location on Mandean Hill, visitors can enjoy a view of the beautiful and green Paksebali Village's beautiful natural scenery.

d. Tourist Accommodation Design

Tourist accommodation is part of a tourist village (Prasyanti et al., 2018). The concept of a tourist accommodation by 
adopting local architecture in its architectural manifestation, with its realization through revitalizing traditional and vernacular architecture that is no longer functional or creating new architecture with local architectural themes (traditional and vernacular). Planning a tourist accommodation makes the interaction between tourists and the local community through a temporary stay in Paksebali Tourism Village. Tourists can enjoy the natural beauty, culture, and traditions of Paksebali Village. In the idea of a tourist village, visitors or tourists enjoy tourist attractions in tourist villages and interact with residents to find out local wisdom (Nuryanti, 1993; Tomic, 2008). This tourist accommodation in Paksebali Tourism Village functions as a stopover for tourists visiting the village. This tourist accommodation is built in an empty area where the shooting range was located. This field is no longer used by the surrounding community to be used as a potential homestay. This homestay has a land area of 3,150 $\mathrm{m}^{2}$ consisting of 8 housing units. Each tourist house unit has an area of $47.5 \mathrm{~m}^{2}$ with two terraces, namely at the front and rear, to accommodate up to 4 people per unit, which can be occupied by adult and child visitors (Figure 7).

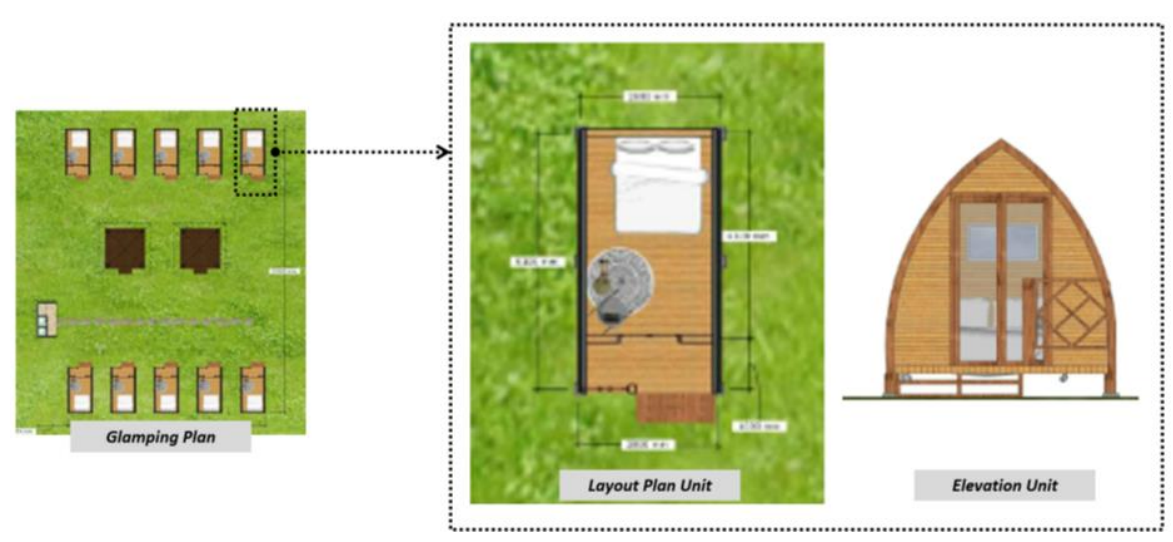

Figure 5. Glamping Design (Source: Author, 2021)

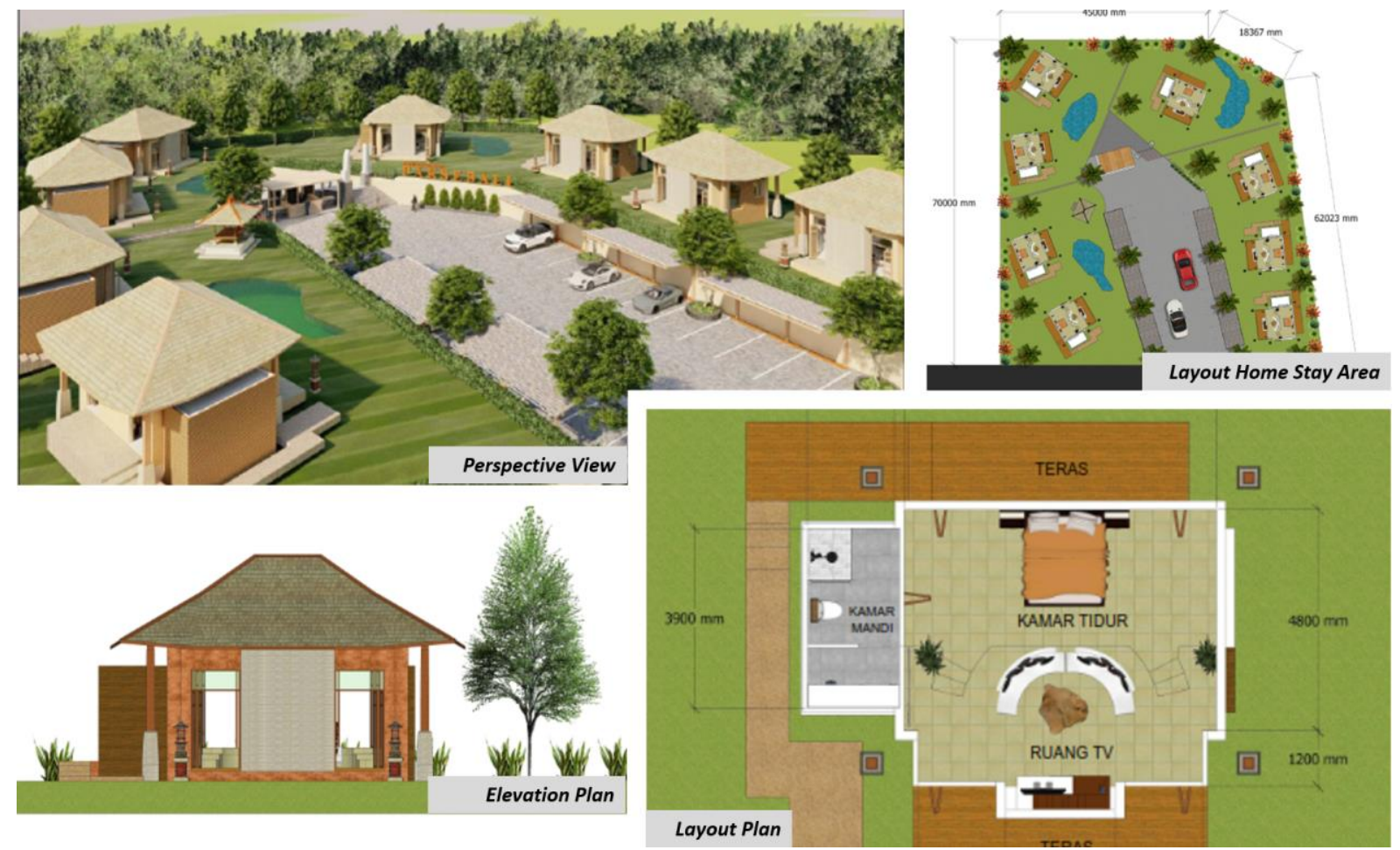

Figure 6. Home Stay Design (Source: Author, 2021)

e. Design of Supporting Facilities for Bukit Mandean Tourism Objects

Accessibility to the Mandean Hill area was initially via two routes, namely Pura Dalem and Pura Kawitan Merajan Agung Dewa Satria Dalem Pegedangan. However, this is unethical, considering that temples are sacred buildings and tourism activities are secular. Therefore, it is proposed to make an impressive entrance to disturb the temple's holy area. We are planning the entry and exit design appropriate to recognize and attract visitors easily. Paths are made using natural rocks to simplify and clarify hiking, cycling paths. Besides, a rest area was also created as a place to rest and a safety post in case of an emergency (Figure 8).

\section{CONCLUSION}

Local potential and sustainability are approaches to the development of Tourism Villages. Independence in potential local governance for this potential's sustainability is a commitment to a Tourism Village concept. Paksebali Tourism Village has a great wealth of potential as a tourist destination developed with attention to sustainability. This sustainability is fundamental as the consistency of this potential is conservative, maintains local characteristics, and becomes a welfare source for local communities. The Paksebali Tourism Village master plan's architectural design transformation requires these considerations (local potential and sustainability). Therefore: 
1. The local potential is a precious asset in the development of a tourist village. These potentials provide the uniqueness of a tourist village, which is an exciting thing for tourists visiting the place. The sustainability of local prospects as the identity of a tourism village must be maintained because the identity has local genius values through wise considerations in village governance. The local potential is natural, cultural, and community capacity in government with local wisdom. Natural potential usually provides benefits from the landscapes contained in an area.

2. Moreover, the natural potential is in the form of landscapes in the form of cultural vegetables. Artistic potential in the form of handicrafts and local dances is also a precious asset because the potential of local culture provides moral messages for the community.

3. Tourism villages to develop based on the local potential to utilize local natural, cultural and human resources. The sense of belonging of the community becomes more muscular, which provides benefits in the economic aspect and provides a sustainable value from these potential resources.

4. Local potentials provide positive sustainability impacts on economic, social, environmental, and cultural aspects. The financial element provides welfare values to the local community evenly because these potentials are part of the village, not individuals or groups. The social piece

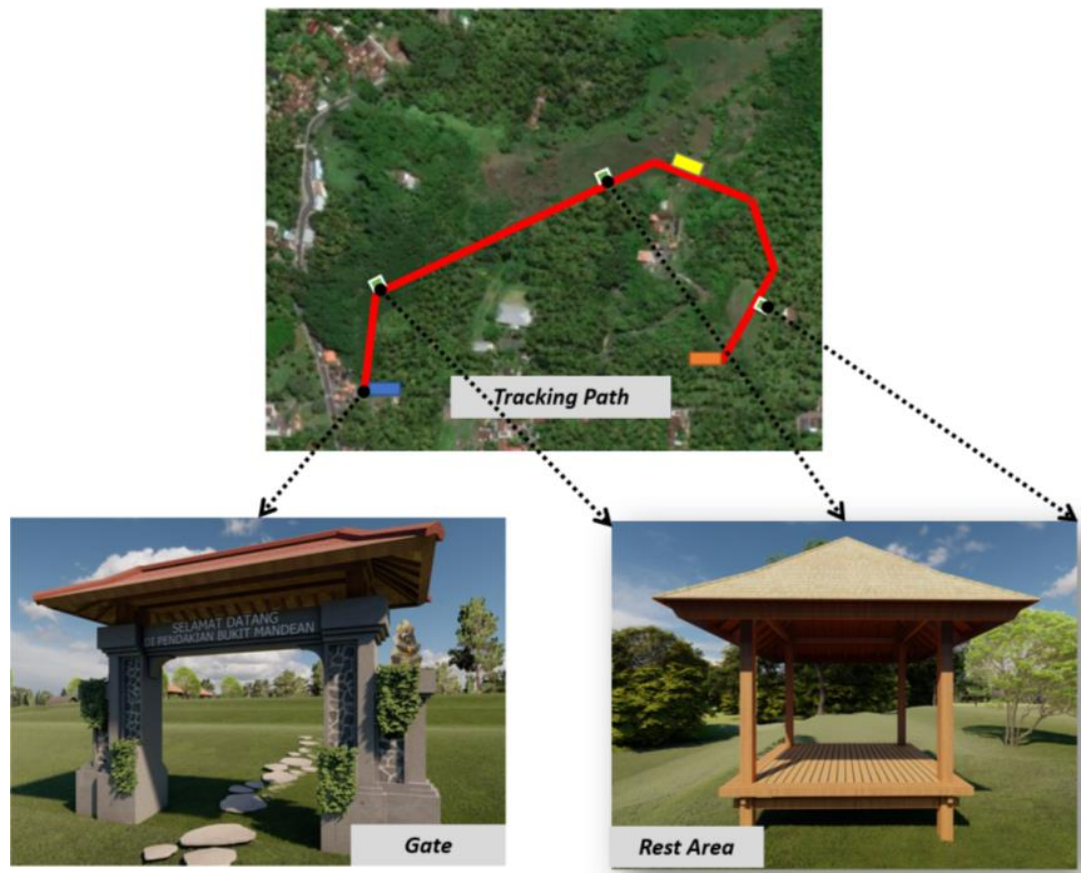

Figure 7. Design of Facilities Supporting Attractions Mandean Hill (Source: Author, 2021) impacts social relations between communities that will be more well-established; there is no social jealousy because of unequal benefits and welfare maintained local potentials in maintaining environmental sustainability. And the cultural potential becomes sustainable by reviving the richness of local culture.

5. Architecture as a physical form in the development of a tourist village must accommodate these local potentials while still paying attention to its sustainability aspects. In this case, sustainable planning and design are needed, considering potential local factors in planning that pay attention to time rather than profit alone. The method of tourism facilities is integrated with local potential, does not bring in building materials from outside the village, does not adopt external architectural styles, and optimizes the appearance of local architecture.

\section{Acknowledgment}

Acknowledgment to the Institute of Community Service, Warmadewa University, for the grants that have been given in funding this research. To the architecture students of Warmadewa University who have assisted indirect involvement in identifying problems and potential of Paksebali Tourism Village. Thank you also to the Tourism Conscious Group in Paksebali Tourism Village, who have been willing to plan Paksebali Tourism Village development.

\section{REFERENCES}

Adebayo, A., Robinson, P., \& Oriade, A. (2019). Community-based tourism. Community-Based Tourism in the Developing World, 98-112, Routledge. https://doi.org/10.4324/9781351026383-8

Asmin, F. (2014). Ecotourism and Sustainable Development: Starting from a Simple Concept. ASMIN Publishing.

Bica, M.S., \& Florescu, E.R. (2017). Sustainable Strategies for Promoting the Horezu Pottery and the Cultural Landscape of Horezu, Romania. Civil Engineering and Architecture, 5(4), 134-140. https://doi.org/10.13189/cea.2017.050402

Buckley, R. (2007). Sustainable Tourism: Theory and Practice. Annals of Tourism Research, 34(1), 269-270.

Budiasa, I.M., Suparta, I.K., \& Nurjaya, I.W. (2019). Implementation of Green Tourism Concept on Glamping Tourism in Bali. Proceedings of the International Conference On Applied Science and Technology 2019 - Social Sciences Track (ICASTSS 2019). https://doi.org/10.2991/icastss-19.2019.44

Butler, R.W. (1999). Sustainable tourism: A state-of-the-art review. Tourism Geographies, 1(1), 7-25. https://doi.org/10.1080/14616689908721291

Cater, C., \& Cater, E. (2015). Ecotourism. International Encyclopedia of the Social \& Behavioral Sciences, 105-109, Elsevier. https://doi.org/10.1016/B978-0-08-097086-8.91071-7

Ching, F.D.K. (2009). Architecture: Form, Space and Order. Erlangga, Jakarta. https://doi.org/10.1177/1087054708326271

Cobbinah, P.B. (2015). Contextualising the meaning of ecotourism. Tourism Management Perspectives, 16, 179-189. https://doi.org/ 10.1016/j.tmp.2015.07.015

Craig, C.A. (2020). Camping, glamping, and coronavirus in the United States. Annals of Tourism Research, 103071. https://doi.org/10.1016/j.annals.2020.103071

Fennell, D. (2008). Ecotourism: Third edition. In Third Edition. Routledge. https://doi.org/10.4324/9780203939581 
Gohar, A., \& Kondolf, G.M. (2016). Sustainable Tourism along the Red Sea: Still Possible? Civil Engineering and Architecture, 4(2), 39-46. https://doi.org/10.13189/cea.2016.040201

Hamzah, A. (2019). Project-based research: quantitative, qualitative and R\&D methods. Literasi Nusantara.

Hardiman, G. (2012). Consideration of humid tropical climate in the concept of modern building architecture. Jurnal Arsitektur Universitas Bandar Lampung, 2(2), 77-82.

Joshi, P.V. (2012). A Stakeholder Networking for Sustainable Rural Tourism Development in Konkan Region of Maharashtra State (India). Golden Research Thoughts, 1(9), 1-4. https://www.yumpu.com/en/document/read/11990242/paresh-vidyadhar-joshi-golden-research-thoughts

Josipa, C.B., Ines, M., \& Zdenko, C. (2017). Glamping - Creative Accommodation In Camping Resorts: Insights And Opportunities. 101114. https://doi.org/10.20867/tosee.04.39

Juan, M., Suárez-Vega, R., \& Santana-Jiménez, Y. (2016). The inter-relationship between rural and mass tourism: The case of Catalonia, Spain. Tourism Management, 54, 43-57. https://doi.org/10.1016/j.tourman.2015.10.015

Khatib, J.M. (2009). Sustainability of construction materials. In Woodhead Publishing Limited. Woodhead Publishing Limited. https://doi.org/10.1533/9781845695842

Komariah, N., Saepudin, E., \& Yusup, P.M. (2018). Local Wisdom Based Tourism Village Development. Jurnal Pariwisata Pesona, 3(2). https://doi.org/10.26905/jpp.v3i2.2340

Manandhar, R., Kim, J.H., \& Kim, J.T. (2019). Environmental, the social, and economic sustainability of bamboo and bamboo-based construction materials in buildings. Journal of Asian Architecture and Building Engineering, 18(2), 49-59. https://doi.org/10.1080/13467581.2019.1595629

Manurung, P. (2014). Sustainable Architecture, Learning From the Wisdom of Archipelago Architecture. Simposium Nasional RAPI XIII 2014 FT UMS.

Marson, D. (2011). From mass tourism to niche tourism. Research themes for tourism, 1-15, CABI. https://doi.org/10.1079/9781845936846.0001

Masjhoer, J.M., Wibowo, D., Sadida, B.Q., \& Ogista, I.T. (2017). Preparation of a Guide Book of Responsible Travel Practices in Mountain Climbing. 11(3). http://ejournal.stipram.ac.id/index.php/kepariwisataan/article/view/33

Mihalic, T. (2016). Sustainable-responsible tourism discourse - Towards 'responsustable' tourism. Journal of Cleaner Production, 111, 461470. https://doi.org/10.1016/j.jclepro.2014.12.062

Muhadjir, N. (2002). Qualitative Research Methodology Edition IV (IV). Rake Sarasin.

Nugroho, A.M. (2018). Nusantara Tropical Architecture: Nusantara Contemporary Tropical House. In UB Press. UB Press.

Nuryanti, W. (1993). Concept, Perspective, and Challenge. Report of the International Conference on Cultural Tourism.

Okazaki, E. (2008). A Community-Based Tourism Model: Its Conception and Use. Journal of Sustainable Tourism, 16(5), 511. https://doi.org/10.2167/jost782.0

Packalén, S. (2010). Culture and sustainability. Corporate Social Responsibility and Environmental Management, 17(2), 118-121. https://doi.org/10.1002/csr.236

Pan, S.Y., Gao, M., Kim, H., Shah, K.J., Pei, S.L., \& Chiang, P.C. (2018). Advances and challenges in sustainable tourism toward a green economy. Science of The Total Environment, 635, 452-469. https://doi.org/10.1016/j.scitotenv.2018.04.134

Pantiyasa, I.W., \& Rosalina, P.D. (2018). The Perception and Participation of Community in Developing Smart Eco-Village Destination in The Tourist Village Paksabali As A Tourism Icon in Klungkung District-Bali. Journal of Business on Hospitality and Tourism, 4(1), 37. https://doi.org/10.22334/jbhost.v4i1.112

Prasyanti, A., Dwikadartomo, A.N., Nuary, A., Noviantori, A., Manta, D.W., Maulany, E.O., Fitriana, E., Suprobowati, G.H., Anggraini, M.L., \& Nataadiningrat, Q. (2018). Tourism Village Homestay Development Guide for the Community. Ministry of Tourism of the Republic of Indonesia.

Sesotyaningtyas, M., \& Manaf, A. (2015). Analysis of Sustainable Tourism Village Development at Kutoharjo Village, Kendal Regency of Central Java. Procedia - Social and Behavioral Sciences, 184, 273-280. https://doi.org/10.1016/j.sbspro.2015.05.091

Soini, K., \& Birkeland, I. (2014). Exploring the scientific discourse on cultural sustainability. Geoforum, 51, $213-223$. https://doi.org/10.1016/j.geoforum.2013.12.001

Sugiono. (2016). Quantitative Research Methods, Qualitative and R \& D. In Alfabeta.

Throsby, D. (1995). Culture, economics, and sustainability. Journal of Cultural Economics, 19(3), 199-206. https://doi.org/10.1007/BF01074049

Tomic, S. (2008). Rural tourism. Jelenkori Társadalmi És Gazdasági Folyamatok, 3(1), 123-127. https://doi.org/10.14232/jtgf.2008.1.123-127

Trisnawati, A.E., Wahyono, H., \& Wardoyo, C. (2018). Tourism Village Development and Community Empowerment Based on Local Potential. Jurnal Pendidikan: Teori, Penelitian, Dan Pengembangan, 3(1), 29-33.

Vainikka, V. (2013). Rethinking Mass Tourism. Tourist Studies, 13(3), 268-286. https://doi.org/10.1177/1468797613498163

Wijaya, I.K.M. (2020). Implementation of Community-Based Ecotourism Concept in Paksebali Tourism Village, Bali, Indonesia. Solid State Technology, 63(5). http://solidstatetechnology.us/index.php/JSST/article/view/5500

Wijaya, I.K.M., \& Nurwarsih, N.W. (2019). Sustainable Tourism Concept in Redesigning Zone-Arrangement on Banyuwedang Hot Springs Architecture. International Journal of Applied Sciences in Tourism and Events, 3(1). https://doi.org/http://dx.doi.org/10.31940/ijaste.v3i1.954

Yanes, A., Zielinski, S., Diaz Cano, M., \& Kim, S. (2019). Community-Based Tourism in Developing Countries: A Framework for Policy Evaluation. Sustainability, 11(9), 2506. https://doi.org/10.3390/su11092506

Article history: Received: 03.03.2021 Revised: 12.04.2021 Accepted: 05.06.2021 Available online: 30.06 .2021 